\title{
Molecular characterisation of Neoparamoeba strains isolated from gills of Scophthalmus maximus
}

\author{
Ivan Fiala ${ }^{1,2}$, Iva Dyková ${ }^{1,2, *}$ \\ ${ }^{1}$ Institute of Parasitology, Academy of Sciences of the Czech Republic and ${ }^{2}$ Faculty of Biological Sciences, \\ University of South Bohemia, Branišovská 31, 37005 České Budějovice, Czech Republic
}

\begin{abstract}
Small subunit ribosomal RNA gene sequences were determined for 5 amoeba strains of the genus Neoparamoeba Page, 1987 that were isolated from gills of Scophthalmus maximus (Linnaeus, 1758). Phylogenetic analyses revealed that 2 of 5 morphologically indistinguishable strains clustered with 6 strains identified previously as $N$. pemaquidensis (Page, 1970). Three strains branched as a clade separated from $N$. pemaquidenis and $N$. aestuarina (Page, 1970) clades. Our analyses suggest that these 3 strains could be representatives of an independent species. In a more comprehensive eukaryotic tree, strains belonging to Neoparamoeba spp. formed a monophyletic group with a sister-group relationship to Vannella anglica Page, 1980. They did not cluster with Gymnamoebae of the families Hartmannellidae, Flabellulidae, Leptomyxidae or Amoebidae presently available in GenBank.
\end{abstract}

KEY WORDS: Paramoeba $\cdot$ Neoparamoeba $\cdot$ SSU rDNA $\cdot$ Phylogenetic position Resale or republication not permitted without written consent of the publisher

\section{INTRODUCTION}

Amoebic gill disease (AGD), repeatedly declared one of the most serious diseases affecting farmed salmonids Salmo salar Linnaeus, 1758 and Oncorhynchus mykiss (Walbaum, 1792) in the last 2 decades (Kent et al. 1988, Munday et al. 1988, 2001, Roubal et al. 1989, Rodger \& McArdle 1996, Findlay \& Munday 1998, Clark \& Nowak 1999, Douglas-Helders et al. 2001), has also been diagnosed in turbot Scophthalmus maximus (Linnaeus, 1758) (Dyková et al. 1998, 2000). Proper identification and systematic classification of the agent and determining its relationship to similar marine amoebae was regarded an important step in the strategy employed to reduce significant stock losses both in salmonids and flatfishes. The small subunit ribosomal ribonucleic acid (SSU rRNA) gene of 6 strains of Neoparamoeba pemaquidensis (Page, 1970) and 1 strain of $N$. aestuarina (Page, 1970) has recently been sequenced in order to develop PCR for detection of the causative agent of AGD (Elliott et al. 2001).
Sequences of the SSU rRNA gene were made accessible in GenBank in May 2002.

As a first step, aimed at unravelling the biology and taxonomy of the agent of AGD in turbot Scophthalmus maximus, comparative light and transmission electron microscopical studies of 6 Neoparamoeba strains indicated that 2 morphologically similar species, $N$. pemaquidensis and $N$. aestuarina have to be considered as agents of AGD in turbot (Dyková et al. 2000).

This communication is intended to describe the molecular characteristics of morphologically identified Neoparamoeba Page, 1987 strains isolated from gills of Scophthalmus maximus to make possible comparison with isolates from other fish and invertebrate hosts.

\section{MATERIALS AND METHODS}

Five Neoparamoeba strains (AFSM2V, AFSM3, AFSM11, SM53 and SM68) isolated from the gills of the turbots Scophthalmus maximus farmed in NW Spain 
were used in this study: 2 strains (SM53, SM68), isolated in 1998, displayed the morphological characteristics described by Dyková et al. (2000); the other 3 strains (AFSM2V, AFSM3, AFSM11) were isolated in 2001. Handling of primary isolates, culture purification, clonal procedures and harvesting of trophozoites followed the methods described by Dyková et al. (2000). The assignment of the strains to the genus Neoparamoeba as defined by Page (1987) was undertaken on fresh mounts (hanging drop preparations) and thin sections prepared for transmission electron microscopy.

Total DNA from samples containing a small amount of cells was extracted using the DNeasy ${ }^{\mathrm{TM}}$ Tissue Kit (Quiagen) according to the manufacturer's protocol. Phenol/chloroform extractions of cell lysates following the protocol of Maslov et al. (1996) were used when a large number of cells $\left(>10^{6}\right)$ were harvested.

Universal eukaryotic primers (5'-ACCTGGTTGATCCTGCCAG-3' and 5'-CTTCCGCTGGTTCACCTACGG$3^{\prime}$ ) (Medlin et al. 1988) were used for amplification of the SSU rRNA gene. PCR was carried out in a $25 \mu \mathrm{l}$ reaction volume using $10 \mathrm{pmol}$ of each primer, $250 \mu \mathrm{M}$ of each deoxyribonucleotide triphosphate (dNTP), and $2.5 \mu \mathrm{l} 10 \times$ PCR buffer (Takara) and 1 Unit of TaqDNA polymerase (Takara). The reactions were run on a T3 thermocycler (Biometra). The thermal cycling pattern was $95^{\circ} \mathrm{C}, 5 \min (\times 1) ; 94^{\circ} \mathrm{C}, 1 \min ^{\circ} 43^{\circ} \mathrm{C}, 2 \min _{i} 72^{\circ} \mathrm{C}$, $2 \min (\times 5) ; 94^{\circ} \mathrm{C}, 1 \min ^{\circ} 48^{\circ} \mathrm{C}, 1 \min ^{\circ} 72^{\circ} \mathrm{C}, 2 \min (\times 25)$; $72^{\circ} \mathrm{C}, 10 \mathrm{~min}(\times 1)$. Amplification products were gel-isolated and cloned into $\mathrm{pCR}^{\circledR}$ 2,1 TOPO cloning vector using the TOPO-TA Cloning Kit (Invitrogen), and sequenced from both strands on an automatic sequencer, CEQ ${ }^{\mathrm{TM}} 2000$ (Beckman Coulter), using the CEQ DTCS Dye Kit (Beckman Coulter) according to the manufacturer's protocol.

For phylogenetic analyses, 2 alignments were performed. For the first alignment the SSU rRNA gene sequences of 5 Neoparamoeba strains from turbot were compared with sequences of 7 Neoparamoeba strains available in GenBank and Vannella anglica Page, 1980 as an outgroup. The second alignment comprised other Gymnamoebia sequences and a set of eukaryotic sequences selected to cover the major groups of eukaryotic taxa. The sequence of a diplomonad species, Hexamita inflata Dujardin, which is considered among the earliest diverging eukaryotes (Leipe et al. 1993), was set as an outgroup. Sequences were aligned in the Clustal X program (Thompson et al. 1997) with various alignment parameters and corrected by eye using the BioEdit sequence alignment editor (Hall 1999). From the second alignment, 7 ambiguously aligned regions (711 sites) were excluded. The alignments are accessible on request. Phylogenetic analyses were performed using the maximum parsimony (MP), maximum likelihood (ML) and distance (minimum evolution, ME) methods. All methods were carried out with the program package PAUP*, version 4.0b10 (Swofford 2001). The MP analysis was done using heuristic search with random addition of taxa (10 replications) and the ACCTRANoption. Gaps were treated as missing data. Transversion:transition (Tv:Ts) ratios were 1:1, 1:2, 1:3, 1:4 and 1:5. For the ML analysis the likelihood ratio test (LRT), implemented in the Modeltest version 3.06 (Posada \& Crandall 1998), was used to determine the best model of evolution. Based on the LRT, the ML was performed with the GTR + G + I evolution model for both alignments $\left(\right.$ GTR $=$ General Time Reversible model $_{i} \mathrm{G}=$ gamma distributed site-to-site variation; and $I=$ proportion of invariable sites; Lanave et al. 1984). The distance method was executed using heuristic search with the minimum evolution as the objective setting. The K2P (Kimura two parameter; Kimura 1980) and HKY (Hasegawa-Kishino-Yuno; Hasegawa et al. 1985) 85 substitution models were used. Genetic distances were calculated with the K2P algorithm. Clade support was assessed by bootstrapping (MP and $\mathrm{ML}=100$ replicates; $\mathrm{ME}=1000$ replicates). The KishinoHasegawa $(\mathrm{KH})$ and Shimodaira-Hasegawa $(\mathrm{SH})$ tests (Kishino \& Hasegawa 1989) were performed by phylogenetic analysis using parsimony (PAUP*) using resampling estimated log-likelihood (RELL) bootstrap (1000 replicates) to assess the significance of differences in likelihood scores of the tree topologies.

\section{RESULTS}

The morphology of the 3 more recently isolated Neoparamoeba strains included in the study (AFSM2V, AFSM3 and AFSM11) corresponded to strains, characterised previously (SM53, SM68) (Dyková et al. 2000). No differences were observed among these 4 strains either at the cellular or ultrastructural level. Also the range in the average length of attached trophozoites did not differ from other Neoparamoeba strains thus far isolated from turbot.

The total length of the SSU rRNA gene in the 5 Neoparamoeba strains was 2065 bp (AFSM2V), 2048 bp (AFSM3), 2061 bp (AFSM11), 2051 bp (SM53) and 2049 bp (SM68). The GenBank accession nos. are: AFSM2V = AY193722, AFSM3 = AY193724, AFSM11 $=\mathrm{AY} 193723, \mathrm{SM} 53=\mathrm{AY} 193726, \mathrm{SM} 68=\mathrm{AY} 193725$. The guanine plus cytosine content was $40.97 \%$ (AFSM2V), $39.40 \%$ (AFSM3), $41.19 \%$ (AFSM11), $39.15 \%$ (SM53) and $40.41 \%$ (SM68). This low content correlates with other sequences of most Gymnamoebia (Bolivar et al. 2001).

The first alignment which comprised 12 Neoparamoeba sequences and 1 sequence of Vannella 
anglica, consisted of 2107 nucleotide sites; of these, 208 sites were parsimony-informative. The distances computed from the first alignment are summarised in Table 1. MP, ML and $\mathrm{ME}$ analyses of the data set resulted in trees with the same topology (Fig. 1). AFSM2V and AFSM11 were the most derivative strains clustered within the Clade A (Fig. 1) as a sister branch to 2 strains isolated from seawater in Wales (UK). Clade A (Fig. 1) is well bootstrapsupported by MP and ME (100\%). Using ML, the same clade has low bootstrap support (57\%). Strains AFSM3, SM53 and SM68 branched out of Clades A and B ( $N$. aestuarina) and composed a monophyletic group-Clade C (Fig. 1) with high bootstrap support.

The second, more comprehensive, analysis was based on alignment of 1730 nucleotide sites and included 52 taxa; 7 ambiguously aligned regions were removed (711 sites). The number of parsimony characters was 1135 . The Neoparamoeba strains clustered together in all analyses performed (MP, ML and ME) and this monophyly was well supported with a $100 \%$ bootstrap value. MP analysis, with Tv:Ts ratios of 1:3, 1:4 and 1:5, and ML analysis (GTR + G+I model) revealed the topology of the tree shown in Fig. 2. Vannella anglica formed the sister branch to the Neoparamoeba spp. clade, but this relation was not bootstrap-supported. The Neoparamoeba spp. clade diverged after division of the Gymnamoebia species and before rapid diversification of the eukaryotic taxa. The branching pattern was different in MP, with a Tv:Ts of $1: 1 ; V$. anglica appeared as an independent lineage diverging just before the Neoparamoeba spp. clade and before the Gym-

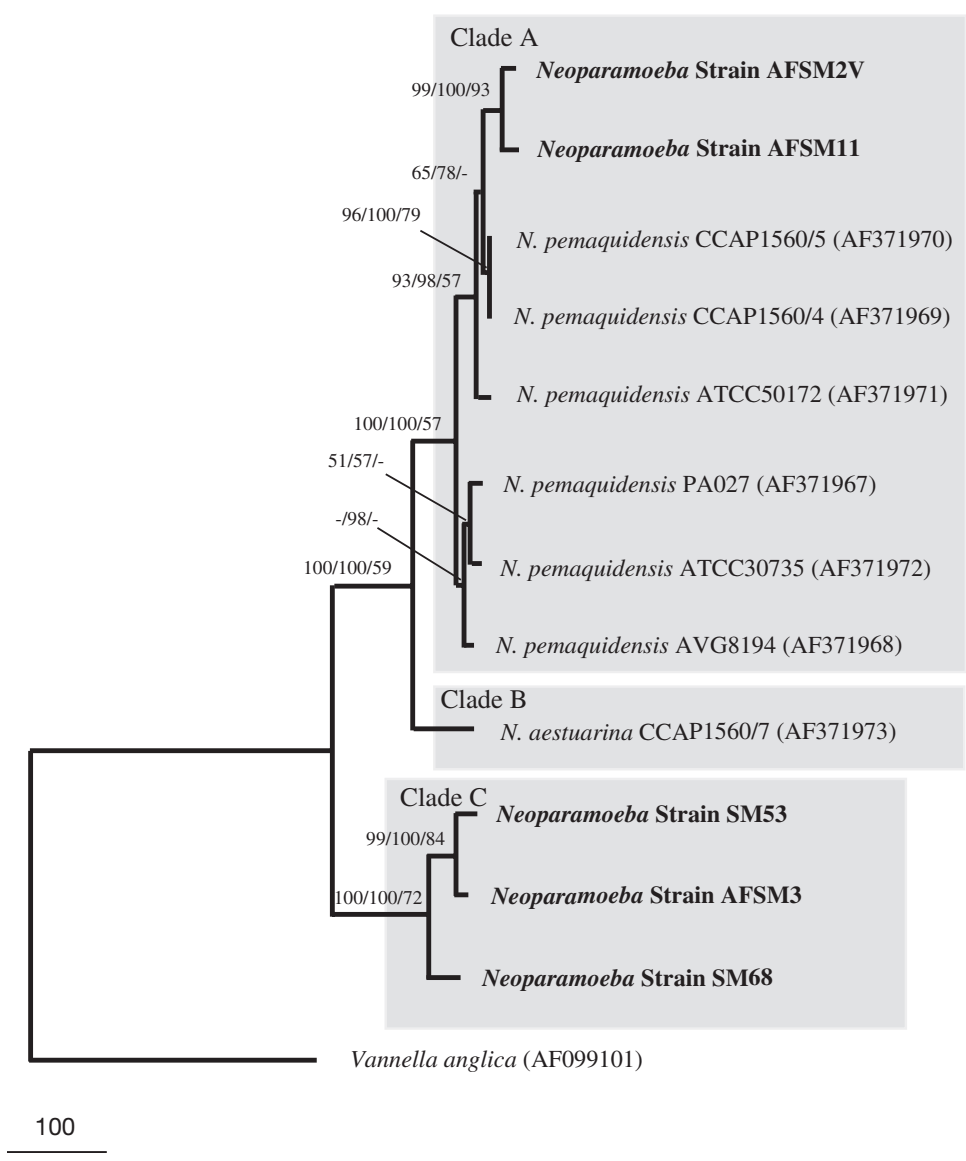

Fig. 1. Phylogenetic analysis comparing gene sequences of 12 Neoparamoeba species with sequence for Vannella anglica. Maximum parsimony (MP) tree (transversion:transition, Tv:Ts ratio $=1: 2 ; 1100$ steps; $\mathrm{CI}=0.87$; Retention Index $[\mathrm{RI}]=0.80$ ) rooted at $V$. anglica. Bootstrap values (MP Tv:Ts 1:2; Kimura two parameter distance method [K2P]; maximum likelihood method [ML]) are indicated for nodes gaining more than $50 \%$ support. GenBank accession nos. in parentheses; distance scale is given under tree

Table 1. Genetic distances (K2P) among 12 Neoparamoeba strains and Vannella anglica strain based on SSU rDNA alignment (2107 nucleotide sites). NP: N. pemaquidensis; NA: N. aestuarina

\begin{tabular}{|c|c|c|c|c|c|c|c|c|c|c|c|c|}
\hline & 1 & 2 & 3 & 4 & 5 & 6 & 7 & 8 & 9 & 10 & 11 & 12 \\
\hline \multicolumn{13}{|l|}{ (1) Strain SM53 } \\
\hline (2) Strain AFSM3 & 0.0133 & & & & & & & & & & & \\
\hline (3) Strain SM68 & 0.0358 & 0.0317 & & & & & & & & & & \\
\hline (4) Strain AFSM2 & 0.0944 & 0.0922 & 0.0944 & & & & & & & & & \\
\hline (5) Strain AFSM11 & 0.0923 & 0.0911 & 0.0894 & 0.0122 & & & & & & & & \\
\hline (6) NA - CCAP1560/7 & 0.0939 & 0.0878 & 0.0914 & 0.0495 & 0.0496 & & & & & & & \\
\hline (7) NP - CCAP 1560/5 & 0.0888 & 0.0888 & 0.0894 & 0.0158 & 0.0168 & 0.0456 & & & & & & \\
\hline (8) NP - CCAP 1560/4 & 0.0888 & 0.0888 & 0.0894 & 0.0158 & 0.0168 & 0.0456 & 0.0000 & & & & & \\
\hline (9) NP - ATCC 50172 & 0.0921 & 0.0921 & 0.0921 & 0.0192 & 0.0183 & 0.0456 & 0.0093 & 0.0093 & & & & \\
\hline (10) NP - PA 027 & 0.0905 & 0.0905 & 0.0922 & 0.0278 & 0.0258 & 0.0439 & 0.0172 & 0.0172 & 0.0187 & & & \\
\hline (11) NP - ATCC 30735 & 0.0866 & 0.0855 & 0.0854 & 0.0258 & 0.0228 & 0.0428 & 0.0177 & 0.0177 & 0.0192 & 0.0108 & & \\
\hline (12 NP - AVG 8194 & 0.0888 & 0.0888 & 0.0888 & 0.0304 & 0.0263 & 0.0428 & 0.0197 & 0.0197 & 0.0207 & 0.0127 & 0.0118 & \\
\hline (13) Vannella anglica & 0.2676 & 0.2677 & 0.2650 & 0.2748 & 0.2705 & 0.2713 & 0.2661 & 0.2661 & 0.2673 & 0.2678 & 0.2662 & 0.2654 \\
\hline
\end{tabular}


namoebia species. ME analysis positioned the Neoparamoeba spp. clade within rapid diversification of eukaryotic taxa. None of the relationships mentioned above was supported by a bootstrap value higher than
$50 \%$. In order to clarify the branching pattern of Neoparamoeba spp. + V. anglica + Gymnamoebia sequences tenuously supported by bootstrapping, $\mathrm{KH}$ and $\mathrm{SH}$ tests were performed (Table 2). The topologies

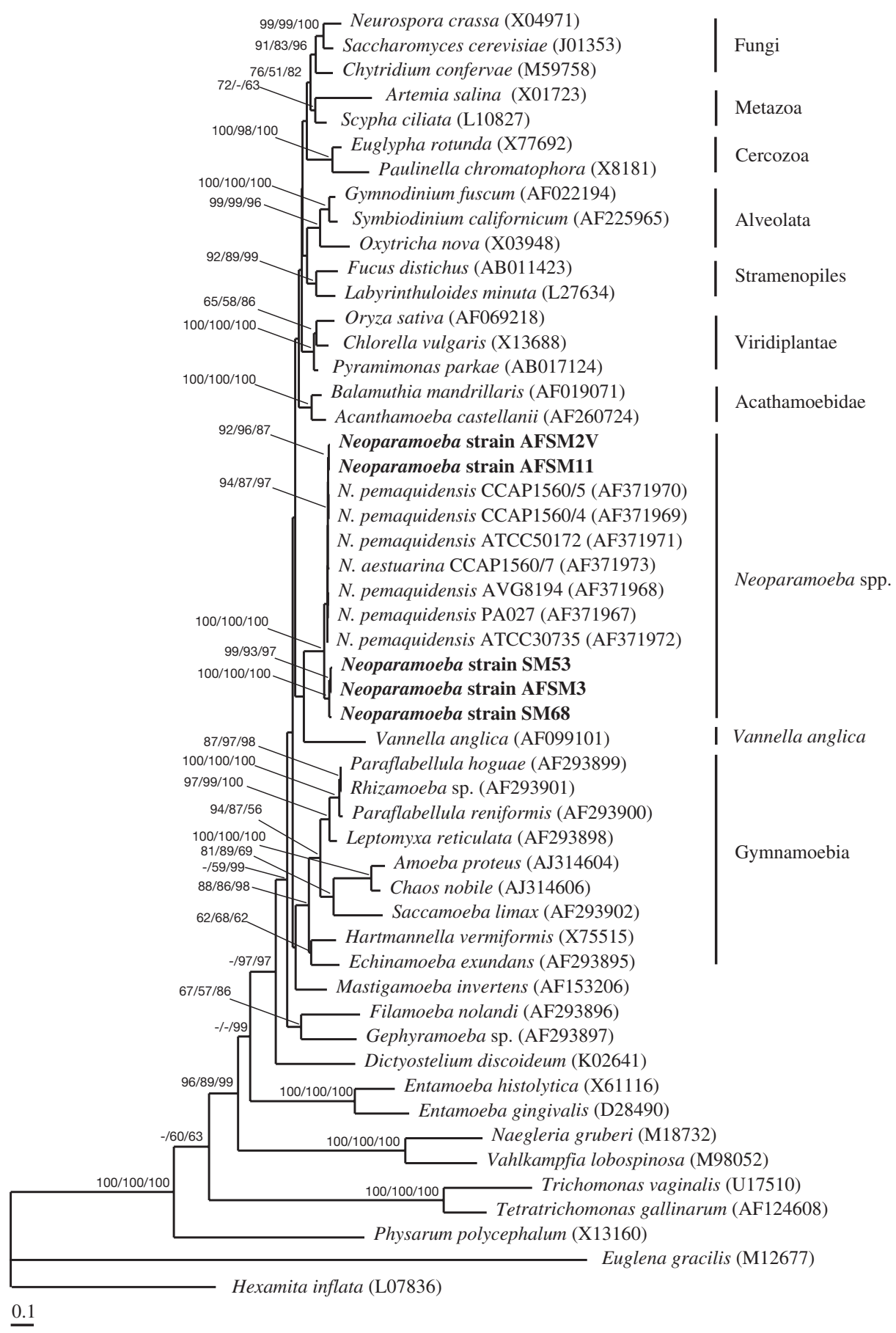

Fig. 2. Phylogenetic analysis comparing gene sequences of major eukaryotic taxa. Maximum likelihood (ML) tree (GTR $+\mathrm{G}+\mathrm{I} ;$ $\alpha=0.510338$, proportion of invariable sites $=0.005179)(-\ln =30643.6814)$ based on $18 \mathrm{~S}$ rRNA gene sequences. The tree is rooted on Hexamita inflata (Diplomonadida). Bootstrap values (ML; MP Tv:Ts = 1:3; distance method K2P) are indicated for nodes gaining more than $50 \%$ support. GenBank accession nos. in parentheses; distance scale is given under tree 
Table 2. Kishino-Hasegawa (KH) and Shimodaira-Hasegawa (SH) tests for constrained trees using RELL bootstrap (1000 replicates). Text form of a tree topology used in the PAUP* program (see also Votýpka et al. 2002). c: eukaryotic taxa with rapid diversification; e: early diverging taxa (Euglena gracilis, Physarum polycephalum, Trichomonas gallinarum, Tetratrichomonas vaginalis, Vahlkampfia lobospinosa, Naegleria gruberi, Entamoeba gingivalis, E. histolytica, Dictyostelium discoideum, Gephyramoeba sp., Filamoeba nolandi); g: Gymnamoebia; h: Hexamita inflata; m: Mastigamoeba invertens; n: Neoparamoeba strains; v: Vannella anglica

\begin{tabular}{|c|c|c|c|c|}
\hline Tree & $-\ln \mathrm{L}$ & Diff $-\ln L$ & $\begin{array}{c}\text { KH-test } \\
\mathrm{p}\end{array}$ & $\begin{array}{c}\text { SH-test } \\
\mathrm{p}\end{array}$ \\
\hline$((\mathrm{h}),((\mathrm{e}),(\mathrm{v},((\mathrm{n}),((\mathrm{m},(\mathrm{g})),(\mathrm{c}))))))$ & 16976.11381 & (best) & & \\
\hline$((\mathrm{h}),((\mathrm{e}),((\mathrm{m},(\mathrm{g})),((\mathrm{v},(\mathrm{n})),(\mathrm{c})))))$ & 16978.39424 & 2.28043 & 0.705 & 0.841 \\
\hline$((\mathrm{h}),((\mathrm{e}),((\mathrm{g}),((\mathrm{m}),((\mathrm{v},(\mathrm{n})),(\mathrm{c}))))))$ & 16983.29615 & 7.18234 & 0.333 & 0.506 \\
\hline$((\mathrm{h}),((\mathrm{e}),(\mathrm{v},((\mathrm{g}),((\mathrm{n}),(\mathrm{m},(\mathrm{c})))))))$ & 16996.62980 & 20.51599 & 0.054 & 0.080 \\
\hline$((\mathrm{h}),((\mathrm{e}),(\mathrm{v},((\mathrm{m},(\mathrm{g})),((\mathrm{n}),(\mathrm{c}))))))$ & 16977.44562 & 1.33181 & 0.684 & 0.855 \\
\hline$((\mathrm{h}),((\mathrm{e}),(\mathrm{v},((\mathrm{g}),(\mathrm{m},((\mathrm{n}),(\mathrm{c})))))))$ & 16982.36173 & 6.24792 & 0.271 & 0.571 \\
\hline$\left((\mathrm{h}),\left((\mathrm{e}),\left((\mathrm{g}),\left(\mathrm{m},\left(\mathrm{v}_{,}(\mathrm{n}),(\mathrm{c})\right)\right)\right)\right)\right)$ & 16988.34037 & 12.22656 & 0.075 & 0.204 \\
\hline$((\mathrm{h}),((\mathrm{e}),(\mathrm{m},(\mathrm{v},(\mathrm{n}),(\mathrm{g}),(\mathrm{c})))))$ & 16989.46696 & 13.35316 & 0.058 & 0.171 \\
\hline$\left((\mathrm{h}),\left((\mathrm{e}),\left(\mathrm{v},(\mathrm{n}), \mathrm{m}_{1}(\mathrm{~g}),(\mathrm{c})\right)\right)\right)$ & 16990.06993 & 13.95612 & $0.046^{*}$ & 0.154 \\
\hline$((\mathrm{h}),((\mathrm{e}),(\mathrm{v},((\mathrm{m},((\mathrm{g}),(\mathrm{n}))),(\mathrm{c})))))$ & 16982.77805 & 6.66424 & 0.279 & 0.563 \\
\hline$((\mathrm{h}),((\mathrm{e}),(\mathrm{m},(\mathrm{v},(\mathrm{g}),(\mathrm{n}))),(\mathrm{c})))$ & 16989.13446 & 13.02065 & 0.132 & 0.222 \\
\hline$((\mathrm{h}),((\mathrm{e}),((\mathrm{m}, \mathrm{v},(\mathrm{g}),(\mathrm{n})),(\mathrm{c}))))$ & 16990.06993 & 13.95612 & $0.046^{*}$ & 0.154 \\
\hline$\left(\mathrm{h},\left((\mathrm{e}),\left(\mathrm{v},\left((\mathrm{g}),\left((\mathrm{n})_{,}(\mathrm{m},((\mathrm{c})))\right)\right)\right)\right)\right)$ & 16980.23762 & 4.12381 & 0.540 & 0.791 \\
\hline$(\mathrm{h},((\mathrm{e}),(\mathrm{v},((\mathrm{n}),((\mathrm{g}),(\mathrm{m},((\mathrm{c}))))))))$ & 16978.87615 & 2.76235 & 0.662 & 0.865 \\
\hline$\left(\mathrm{h},\left((\mathrm{e})_{,}((\mathrm{v},(\mathrm{n})),((\mathrm{g}),(\mathrm{m},((\mathrm{c})))))\right)\right)$ & 16980.61881 & 4.50500 & 0.561 & 0.724 \\
\hline$((\mathrm{h}),((\mathrm{e}),((\mathrm{v},(\mathrm{n})),((\mathrm{m},(\mathrm{g})),(\mathrm{c})))))$ & 16977.44706 & 1.33325 & 0.788 & 0.892 \\
\hline$((\mathrm{h}),((\mathrm{e}),((\mathrm{n}),((\mathrm{m},(\mathrm{g})),(\mathrm{v},(\mathrm{c}))))))$ & 16983.51360 & 7.39979 & 0.116 & 0.486 \\
\hline$((\mathrm{h}),((\mathrm{e}),((\mathrm{n}),(\mathrm{v},((\mathrm{m},(\mathrm{g})),(\mathrm{c}))))))$ & 16980.73244 & 4.61863 & 0.243 & 0.668 \\
\hline${ }^{*} \mathrm{p}<0.05$ & & & & \\
\hline
\end{tabular}

described above plus the alternative tree topologies determined for ML under the $(\mathrm{GTR}+\mathrm{G}+\mathrm{I})$ evolution model were tested. Only the topologies with Mastigamoeba invertens branching together with the clade of Neoparamoeba, Gymnamoebia and V. anglica and also with the 'crown taxa' clade were rejected by the KH test $(\mathrm{p}<0.05)$.

\section{DISCUSSION}

Our phylogenetic analyses confirmed a close relationship of 5 mutually morphologically indistinguishable Neoparamoeba strains from Scophthalmus maximus with 6 strains of $N$. pemaquidensis, and 1 strain of $N$. aestuarina characterised by Elliot et al. (2001). The topology of the tree (Fig. 1) and genetic distances (Table 1) revealed a very close relationship between 2 turbot strains (AFSM2V and AFSM11) and N. pemaquidensis strains. The closest was the affinity with CCAP 1560/4 and CCAP 1560/5 strains of N. pemaquidensis isolated from seawater in Wales, and also with ATCC 50172 strain of the same species isolated from Oncorhynchus kisutch (Walbaum, 1792) in the USA. The remaining 3 strains under study (Clade C) clearly branched out of $N$. pemaquidensis and $N$. aestuarina clades. Although morphologically indistinguishable, they represented a lineage distinctly separated from the other Neoparamoeba strains and thus could be independent species.

The phylogenetic position of Gymnamoebae and their relation to other organisms has been thoroughly discussed by Bolivar et al. (2001) and earlier investigations (Silberman et al. 1999, Sims et al. 1999, Amaral Zettler et al. 2000). Our SSU rDNA analyses indicate a common evolutionary history of Neoparamoeba spp. and Vannella anglica. Previous phylogenetic studies (Sims et al. 1999, Bolivar et al. 2001) classed $V$. anglica as an independent lineage diverging before the Gymnamoebia species sequenced thus far. Our results show a sistergroup relation of the recently sequenced Neoparamoeba strains with $V$. anglica. Both genera have morphological features typical of Gymnamoebae (Page 1987). The results of our phylogenetic analyses of SSU rRNA gene sequences indicate that Neoparamoeba sequences do not cluster with species of the Gymnamoebia (sensu stricto according to Bolivar et al. 2001). Depending on the model of evolution, the branching pattern of the tree changed and the overall bootstrap support was low, so that we could not accurately determine the real position of the Neoparamoeba clade. $\mathrm{KH}$ and $\mathrm{SH}$ tests also failed to clarify this. Further studies focused on sequencing early diverging taxa will hopefully solve some of these problems.

Acknowledgements. The authors express their sincere appreciation to the Grant Agency of the Czech Republic and to the Ministry of Education, Youth and Sports of the Czech Republic for finacial support (Projects no. 206/00/0265 and MSM 12300003); to Dr. Miroslav Oborník and Dr. Václav Hypša for their guidance in the field of molecular and phylogenetic methods, and to Dr. Blanka Macháčková and Dr. Hana Pecková for their technical assistance.

\section{LITERATURE CITED}

Amaral Zettler LA, Nerad TA, O'Kelly CJ, Peglar MT, Gillevet PM, Silberman JD, Sogin ML (2000) A molecular reassessment of the leptomyxid amoebae. Protistologica 151: 275-282

Bolivar I, Fahrni JF, Smirnov A, Pawlowski J (2001) SSU 
rRNA-based phylogenetic position of the genera Amoeba and Chaos (Lobosea, Gymnamoebia): the origin of Gymnamoebae revisited. Mol Biol Evol 18:2306-2314

Clark A, Nowak B (1999) Field investigations on amoebic gill disease in Atlantic salmon, Salmo salar L. in Tasmania. J Fish Dis 22:433-443

Douglas-Helders M, Carson J, Howard T, Nowak B (2001) Development and validation of a new dot blot test for the detection of Paramoeba pemaquidensis (Page) in fish. J Fish Dis 24:273-280

Dyková I, Figueras A, Novoa B, Fernandez-Casal J (1998) Paramoeba sp., an agent of amoebic gill disease of turbot Scophthalmus maximus. Dis Aquat Org 33:137-141

Dyková I, Figueras A, Peric Z (2000) Neoparamoeba Page, 1987: light and electron microscopic observations on six strains of different origin. Dis Aquat Org 43:217-223

Elliott NG, Wong F, Carson J (2001) Detection and abundance of Paramoeba species in the environment. CSIRO Marine Research, Hobart

Findlay VL, Munday BL (1998) Further studies on acquired resistance to amoebic gill disease (AGD) in Atlantic salmon, Salmo salar L. J Fish Dis 21:121-125

Hall TA (1999) BioEdit: a user-friendly biological sequence alignment editor and analysis program for Windows 95/98/NT. Nucleic Acids Symp Ser 41:95-98

Hasegawa M, Kishino H, Yano T (1985) Dating the humanape split by a molecular clock of mitochrondrial DNA. J Mol Evol 22:160-174

Kent ML, Sawyer TK, Hedrick RP (1988) Paramoeba pemaquidensis (Sarcomastigophora: Paramoebidae) infestation of the gills of coho salmon Oncorhynchus kisutch reared in seawater. Dis Aquat Org 5:163-169

Kimura M (1980) A simple method for estimating evolutionary rates of base substitutions through the comparative studies of sequence evolution. J Mol Evol 16:111-120

Kishino H, Hasegawa M (1989) Evaulation of the maximumlikelihood estimate of the evolutionary tree topologies from DNA-sequence data and the branching order in Hominoidea. J Mol Evol 29:170-179

Lanave C, Preparata G, Saccone C, Serio G (1984) A new method for calculating evolutionary substitution rates. J Mol Evol 20:86-93

Leipe DD, Gunderson JH, Nerad TA, Sogin ML (1993) Small subunit ribosomal RNA of Hexamita inflata and the quest for the 1st branch in the eukaryotic tree. Mol Biochem Parasitol 59:41-48

Editorial responsibility: Wolfgang Körting,

Hannover, Germany
Maslov DA, Lukeš J, Jirki̊ M, Simpson L (1996) Phylogeny of trypanosomes as inferred from the small and large subunit rRNAs: implications for the evolution of parasitism in the trypanosomatid protozoa. Mol Biochem Parasit 75: 197-205

Medlin L, Elwood HJ, Stickel S (1988) The characterization of enzymatically amplified eukaryotic 16S-like rRNA-coding regions. Gene 71:491-499

Munday BL, Foster CK, Roubal FR, Lester RJG (1988) Paramoebic gill infection of Atlantic salmon (Salmo salar) and rainbow trout (Salmo gairdneri). In: Perkins FO, Cheng TC (eds) Third International Colloquium on Pathology in Marine Aquaculture, Virginia Institute of Marine Science, Gloucester Point, p 53-54

Munday BL, Zilberg D, Findlay V (2001) Gill disease of marine fish caused by infection with Neoparamoeba pemaquidensis. J Fish Dis 24:497-507

Page FC (1987) The classification of 'naked' amoebae of phylum Rhizopoda. Arch Protistenkd 133:199-217

Posada D, Crandall KA (1998) Modeltest: testing the model of DNA substitution. Bioinformatics 14:817-818

Rodger HD, McArdle JF (1996) An outbreak of amoebic gill disease in Ireland. Vet Rec 139:348-349

Roubal FR, Lester RJG, Foster CK (1989) Studies on cultured and gill attached Paramoeba sp. (Gymnamoebae: Paramoebidae) and the cytopathology of paramoebic gill disease in Atlantic salmon, Salmo salar L., from Tasmania. J Fish Dis 12:481-493

Silberman JD, Clark CG, Diamond LS, Sogin MS (1999) Phylogeny of the genera Entamoeba and Endolimax as deduced from small-subunit ribosomal RNA sequences. Mol Biol Evol 16:1740-1751

Sims GP, Rogerson A, Aitken R (1999) Primary and secondary structure of the small subunit ribosomal RNA of the naked, marine amoeba Vannella anglica: phylogenetic implications. J Mol Evol 48:740-749

Swofford DL (2001) PAUP*: phylogenetic analysis using parsimony, version 4.0b10, Sinauer Associates, Sunderland, MA

Thompson JD, Gibson TJ, Plewniak F, Jeanmougin F, Higgins DG (1997) The CLUSTAL_X windows interface: flexible strategies for multiple sequence alignment aided by quality analysis tools. Nucleic Acids Res 25:4876-4882

Votýpka J, Obornik M, Volf P, Svobodova M, Lukes J (2002) Trypanosoma avium of raptors (Falconiformes): phylogeny and identification of vectors. Parasitology 125:253-263

Submitted: July 29, 2002; Accepted: December 20, 2002

Proofs received from author(s): March 28, 2003 